Tersedia Online di http://journal.unismuh.ac.id/index.php/otoritas

Otoritas : Jurnal Ilmu Pemerintahan, 7 (1), April 2017, 19-27

\title{
Efektivitas E-Musrenbang di Kota Surabaya dalam Sistem Perencanaan Pembangunan Berparadigma Masyarakat
}

\author{
Novy Setia Yunas*) \\ Program Studi Ilmu Pemerintahan, Fakultas Ilmu Sosial dan Ilmu Politik, Universitas Darul Ulum, \\ Jalan KH. Abdurrahman Wahid No.29, Kab. Jombang 61413, Jawa Timur, Indonesia
}

Diterima: 28 Januari 2017; Disetujui: 18 Maret 2017; Dipublikasikan: 14 April 2017

\begin{abstract}
The success of the development in a region will be greatly determined by the quality of development planning. As planning became the sign posts are clear about what the needs of the citizens with has clear and measurable targets. Development Planning System emphasizes a combination of approaches between top-down and bottom up, which emphasizes the ways aspirational and participatory, so it is realized through the process of development planning or deliberation Musrenbang neighborhood start at various levels up to nationwide. This paper is the result of research that are descriptive studies library which describes the process of implementing E-Musrenbang in Surabaya with a variety of problems. E-Musrenbang successfully applied in Surabaya at least be innovations in development planning system in which during this society wants a forum or social contacts among citizens with the Government in regional development planning. The application of the system of EMusrenbang in Surabaya became an important lesson for the construction paradigm of society, where society is not only made of the objects but rather the subject of development.
\end{abstract}

Keywords: Development Planning; Participatory; E-Musrenbang

\begin{abstract}
Abstrak
Keberhasilan pembangunan di suatu wilayah ditentukan oleh kualitas perencanaan pembangunannya. Sebagaimana perencanaan menjadi penunjuk arah yang jelas tentang apa yang menjadi kebutuhan warga dengan target yang jelas dan terukur. Sistem perencanaan menekankan kombinasi pendekatan antara top-down dan bottom-up, yang lebih menekankan cara-cara aspiratif dan partisipatif, sehingga hal tersebut diwujudkan melalui proses musyawarah perencanaan pembangunan atau Musrenbang di berbagai tingkatan mulai kelurahan hingga Nasional. Tulisan ini merupakan hasil penelitian yang bersifat deskriptif dengan studi kepustakaan yang menjelaskan proses pelaksanaan E- Musrenbang di Surabaya dengan berbagai permasalahannya. Sistem EMusrenbang yang berhasil diterapkan di Kota Surabaya setidaknya menjadi inovasi dalam sistem perencanaan pembangunan dimana selama ini masyarakat menginginkan sebuah forum atau kontak sosial antara warga dengan pemerintah dalam perencanaan pembangunan daerah. Penerapan sistem E- Musrenbang di Kota Surabaya menjadi sebuah pelajaran penting bagi perencanaan pembangunan berparadigma masyarakat, dimana masyarakat tidak hanya dijadikan objek melainkan subjek pembangunan.
\end{abstract}

Kata kunci : Perencanaan Pembangunan; Partisipatif; E-Musrenbang

Cara Penulisan Sitasi: Yunas, N. S. (2017). Efektivitas E-Musrenbang di Kota Surabaya dalam Sistem Perencanaan Pembangunan Berparadigma Masyarakat. Otoritas : Jurnal Ilmu Pemerintahan, 7(1), 19-27.

*)Penulis Korespondensi.

E-Mail : novysetiayunas@gmail.com

Copyright (C) 2017, Otoritas : Jurnal Ilmu Pemerintahan, p-ISSN: 2088-3706, e-ISSN: 2502-9320 
Tersedia Online di http://journal.unismuh.ac.id/index.php/otoritas

Otoritas : Jurnal Ilmu Pemerintahan, 7 (1), April 2017, 20

\section{Pendahuluan}

Perencanaan merupakan bagian dasar dalam manajemen pembangunan. Perencanaan pada asasnya berkisar pada dua hal, pertama adalah penentuan secara sadar mengenai tujuan-tujuan konkret yang hendak dicapai dalam jangka waktu tertentu atas dasar nilai-nilai yang dimiliki masyarakat bersangkutan, dan yang kedua adalah pemilihan diantara caracara alternatif yang efisien serta rasional guna mencapai tujuan- tujuan tersebut (Mustopadidjaja, 2012). Oleh karena itu, untuk dapat menjalankan suatu pembangunan nasional yang baik diperlukan suatu perencanaan yang matang sehingga tujuan- tujuan yang ingin dicapai dan usaha usaha yang akan dilakukan untuk mencapai tujuan tersebut dapat dilaksanakan.

Di Indonesia, berakhirnya masa pemerintahan Orde Baru pada tahun 1998 telah merubah secara fundamental dasar-dasar penyelenggaraan pemerintahan. Salah satu yang paling jelas adalah terjadinya perubahan sistem pemerintahan sentralisitik menjadi desentralistik, yang ditandai dengan lahirnya UU No. 22 tahun 1999 tentang Pemerintahan Daerah, yang kemudian direvisi oleh UU No. 32 tahun 2004. Perubahan tersebut juga berimplikasi pada sistem perencanaan pembangunan yang sebelumnya, seperti apa yang telah disampaikan Bappenas (2005), dimana proses perencanaan pembangunan lebih banyak diwarnai oleh permasalahan inkonsistensi kebijakan, rendahnya partisipasi masyarakat, ketidakselarasan antara perencanaan program dan pembiayaan, rendahnya transparansi dan akuntabilitas, serta kurang efektifnya penilaian kinerja. Seiring dengan pemberian kewenangan yang lebih luas kepada daerah dalam rangka implementasi otonomi daerah, maka UU No. 25 tahun 2004 tentang Sistem Perencanaan Pembangunan Nasional diterbitkan dalam rangka mengatasi permasalahan perma- salahan tersebut (Dasgupta, 2004).

Berbeda dengan sistem perencanaan sebelumnya yang lebih menganut pendekatan topdown, sistem perencanaan yang diatur dalam UU No. 25 tahun 2004 dan aturan pelaksanaannya menerapkan kombinasi pendekatan antara top-down dan bottom-up, yang lebih menekankan cara-cara aspiratif dan partisipatif. Dalam tataran global, kesadaran akan kelemahan pendekatan top-down dalam kegiatan pembangunan dan upaya pengentasan kemiskinan telah mendorong munculnya perhatian pada peranan partisipasi masyarakat dan pentingya memahami dinamika masyarakat dan pemerintah daerah serta interaksinya dengan pemerintahan yang lebih tinggi (Dasgupta, 2004).

Terbukanya ruang partisipasi dan aspirasi masyarakat yang lebar kemudian mendorong anggota masyarakat untuk dapat bergerak bersama dalam menyampaikan aspirasinya. Dalam sebuah studi menunjukkan bahwa peran aksi kolektif dalam membuat suara masyarakat lebih terdengar dan membuka peluang untuk memberikan pengaruh terhadap keputusan-keputusan sebuah institusi mengenai pelayanan publik (Teguh, 2004). Aksi kolektif tersebut kemudian mendorong masyarakat lebih siap untuk terlibat dalam proses partisipasi. Pendekatan top-down dan partisipatif sesuai amanat UU No. 25 tahun 2004 terwujud dalam sebuah bentuk rangkaian musrenbang yang dilakukan secara berjenjang dari mulai tingkat desa, kecamatan dan kabupaten.

Rangkaian forum musrenbang ini menjadi bagian dalam proses penyusunan sistem perencanaan dan anggaran untuk pelaksanaan kegiatan pembangunan setiap tahunnya. Melalui musrenbang, masyarakat berpeluang menyampaikan aspirasi mereka dan berpartisipasi dalam menghasilkan dokumen perencanaan pembangunan yang sesuai dengan kebutuhan masyarakat. 
Tersedia Online di http://journal.unismuh.ac.id/index.php/otoritas

Otoritas : Jurnal Ilmu Pemerintahan, 7 (1), April 2017, 21

Seiring dengan perkembangan zaman dan kebutuhan untuk semakin membuka ruang partisipasi dan aspirasi masyarakat dalam proses perencanaan pembangunan di daerah, rangkaian forum musrenbang tak hanya diwujudkan melalui instrument yang manual dan formal seperti yang dilakukan selama ini. EMusrenbang merupakan sebuah inovasi dalam sistem perencanaan pembangunan daerah dengan mengadopsi perkembangan teknologi, informasi dan komunikasi. Keberadaan E- Musrenbang dinilai mampu membuka ruang partisipasi masyarakat dari segala tingkatan untuk memberikan aspirasi terkait pembangunan yang sesuai dengan kebutuhan masyarakat. Sudah banyak daerah yang dinilai berhasil menerapkan sistem EMusrenbang sebagai salah satu instrumen perencanaan pembangunan seperti di Kota Surabaya, Tangerang Selatan, DKI Jakarta, Sumatera Selatan dan bahkan dalam perencanaan pembangunan Nasional pun Bappenas kini mulai menggunakan sistem berbasis teknologi dan informasi tersebut.

Pola sistem komunikasi E- Musrenbang ini dinilai mampu menjadi sebuah inovasi dalam proses perencanaan pembangunan di Indonesia dan seluruh daerah karena penerapan aplikasi eMusrenbang menyajikan data akurat, kegiatan tepat sasaran, pengelompokkan jenis usulan pekerjaan lebih mudah hingga memperpendek waktu rekapitulasi data usulan. E-Musrenbang ini nantinya meliputi perencanaan yang perwujudannya adalah proses musrenbang Tingkat Kelurahan, Tingkat Kecamatan, Tingkat Kota (Forum SKPD dan Musrenbang Tingkat Kota), bergulir terus menjadi KUA-PPAS (Kebijakan Umum Anggaran- Penetapan Plafon Anggaran Sementara), penetapan R-APBD yang dirapatkan dengan legislatif, sampai pada penetapan APBD. Sistem aplikasi E-Musrenbang ini berbasis internet sehingga penerapannya tidak hanya sesuai dengan UU No. 25 tahun 2004 ten- tang sistem perencanaan pembangunan melainkan Inpres No. 3 tahun 2003 tentang Kebijakan Strategi Nasional Elektronik Government (E-Government).

Berdasarkan pada penelitian dan hasil publikasi sebelumnya yang secara spesifik membahas terkait E-Musrenbang dan pentingnya teknologi dalam proses pembangunan masyarakat dibahas oleh Angeline, Evelina, \& Siregar (2016) dengan melakukan perbandingan tingkat keberhasilan penggunaan Government Digital Public Services antara DKI Jakarta dan Kota Surabaya sebagai kota terbesar di Indonesia. Perbandingan ini berdasarkan pada kesiapan, keterampilan dan kompetensi sumber daya manusia, hingga respon masyarakat yang belum memperdulikan keberadaan layanan yang disediakan.

Bahasan tentang E-Musrenbang dijelaskan oleh Masrizal (2016) dalam kaitannya dengan keberhasilan sistem ini dalam memberikan edukasi kepada kelompok perempuan di Aceh yang mengadakan musyawarah rencana aksi perempuan dan hubungannya dengan rencana pembangunan kampung di daerah tersebut.

Sedangkan artikel ini akan menganalisa keberadaan E-Musrenbang sebagai sebuah inovasi dalam sistem perencanaan pembangunan nasional yang dinilai mampu mengakomodir kebutuhan masyarakat (pendekatan partisipatif) dalam proses perencanaan pembangunan daerah yang berkualitas khususnya di daerah Surabaya. Selain itu, apakah keberadaan E-Musrenbang sudah cukup efektif dalam sistem Perencanaan Pembangunan Nasional sesuai dengan UU No. 25 tahun 2004.

\section{Metode Penelitian}

Penelitian ini bersifat deskriptif dengan studi kepustakaan (library research), yang menerangkan pelaksanaan e-Musrenbang di Surabaya dengan berbagai permasalahannya. Library re- 
search merupakan penelitian yang dilakukan berdasarkan informasi dari publikasi ilmiah, penelitian terdahulu, ataupun sumber tertulis lain yang mendukung. Sumber informasi utama dalam penelitian ini diperoleh melalui analisis publikasi hasil penelitian sebelumnya dan dokumen lain yang terkait dengan tujuan kajian. Dalam penelitian ini, proses analisa data yang digunakan adalah analisa data kualitatif. Analisis dan interpretasi atau penafsiran ini dilakukan dengan merujuk kepada landasan teoritis yang berhubungan dengan masalah penelitian.

\section{Hasil dan Pembahasan}

Keberhasilan pembangunan di suatu wilayah pemerintahan akan sangat ditentukan oleh bagaimana kualitas perencanaan pembangunannya. Seperti dipahami bahwa perencanaan akan menunjukan arah yang jelas tentang apa yang menjadi kebutuhan warga dalam periode tertentu. Dengan perencanaan, semua kegiatan pembangunan dalam berbagai sektor memiliki target yang jelas dan terukur. Oleh karena itu perencanaan akan memudahkan para pelaku pembangunan dalam mencapai target- target yang telah ditentukan. Namun demikian, untuk memastikan bahwa pencapaian hasil agar sesuai dengan rencana maka diperlukan adanya pengendalaian atau pengawasan. Proses penyusunan rencana pembangunan di Negara kita secara normatif mengikuti sistem politik yang berlaku yakni sistem politik demokratis dimana sistem politik ini akan menjadi dasar semua kegiatan pemerintahan, termasuk kegiatan perencanaan pembangunan yang senantiasa melibatkan semua pemangku kepentingan dalam pemerintahan Negara. Diantara elemen-elemen pemangku kepentingan yang utama adalah pemerintah, masyarakat dan swasta. Sesuai dengan UU No. 25 Tahun 2004 Tentang Sistem Perencanaan Pembangunan Nasional, bahwa mekanisme penyusunan rencana pembangunan, baik di tingkat pusat maupun daerah dilakukan melalui mekanisme forum yang disebut dengan musyawarah perencanaan pembangunan Musrenbang. Jadi Musrenbang merupakan forum antar aktor dalam rangka menyusun rencana pembangunan nasional maupun rencana pembangunan daerah. Dari forum Musrenbang tersebut akan menghasilkan dokumen perencanaan pembangunan yang berupa rencana- rencana pembangunan dalam jangka panjang, jangka menengah, dan tahunan yang dilaksanakan oleh unsur penyelenggara Negara dan masyarakat.

Seiring dengan perkembangan zaman dan kebutuhan untuk semakin membuka ruang partisipasi dan aspirasi masyarakat dalam proses perencanaan pembangunan di daerah, rangkaian forum musrenbang kini tak hanya diwujudkan melalui instrument yang manual dan formal seperti yang dilakukan selama ini. Kehadiran E- Musrenbang merupakan sebuah inovasi dalam sistem perencanaan pembangunan daerah dengan mengadopsi perkembangan teknologi, informasi dan komunikasi. E- Musrenbang dinilai mampu membuka ruang partisipasi masyarakat dari segala tingkatan untuk memberikan aspirasi terkait pembangunan yang sesuai dengan kebutuhan masyarakat. Sudah banyak daerah yang dinilai berhasil menerapkan sistem EMusrenbang sebagai salah satu instrumen perencanaan pembangunan seperti Kota Surabaya, Tangerang Selatan, DKI Jakarta, Sumatera Selatan dan bahkan dalam perencanaan pembangunan Nasional pun Bappenas kini mulai menerapkan sistem berbasis teknologi dan informasi tersebut.

Penerapan Elektronik Musyawarah Rencana Pembangunan atau EMusrenbang ini merupakan inovasi sistem komunikasi antara pemerintah dan masyarakat yang diyakini dapat menyajikan data lebih akurat dan lebih efektif menyaring usulan warga. 
Tersedia Online di http://journal.unismuh.ac.id/index.php/otoritas

Otoritas : Jurnal Ilmu Pemerintahan, 7 (1), April 2017, 23

Pemakaian E-Musrenbang mendorong transparansi dan akutabilitas data usulan yang masuk dari masyarakat (Leba, 2015). Pola sistem komunikasi Emusrenbang ini bisa menjadi inovasi sistem perencanaan pembangunan bagi Indonesia dan seluruh kepala daerah lainnya karena penerapan aplikasi Sistem Informasi Manajemen Penganggaran dan Pelaporan (Simral) e- Musrenbang menyajikan data akurat, kegiatan yang tepat sasaran, pengelompokkan jenis usulan pekerjaan lebih mudah hingga memperpendek waktu rekapitulasi data usulan.

Dalam menginput data usulan program pembangunan yang masuk digunakan aplikasi Sistem Informasi Manajemen Penganggaran dan Pelaporan (Simral). Sesuai dengan namanya, Simral meliputi perencanaan yang perwujudannya adalah proses musrenbang tingkat Kelurahan, tingkat Kecamatan, Tingkat Kota (Forum SKPD dan Musrenbang Tingkat Kota), bergulir terus menjadi KUA-PPAS (Kebijakan Umum Anggaran- Penetapan Plafon Anggaran Sementara), penetapan RAPBD yang dirapatkan dengan legislatif, sampai pada penetapan APBD. Masyarakat yang ingin mengetahui usulan kegiatan di wilayahnya dapat dengan mudah mengakses informasinya melalui situs E- Musrenbang yang ada. Pada tahapan perencanaan dan pengganggaran, dinamika perubahan sangat tinggi dan komplek. Selesai ditetapkan sebagai KUAPPAS, alokasi anggaran dibahas dalam acara rapat dengar pendapat (hearing) antara legislatif dengan SKPD terkait, yang berpotensi terjadi perubahaan dalam berbagai sisi. Dengan Simral setiap kejadian perubahan tersimpan dan tercatat dalam Simral.

Dalam proses perencanaan anggaran, Simral menyusun dan mencatat tiga tahap atau tiga jenis RAPBD - RAPBD saat diajukan ke legislatif oleh Tim Anggaran Eksekutif, RAPBD persetujuan bersama antara Eksekutif dan legeslatif, dan
APBD hasil revisi Pemerintah Provinsi. Semua tercatat dalam Sistem. Pada saat peyusunan DPA, setiap kegiatan yang dilakukan oleh SKPD dapat terpantau secara real time. Pimpinan dapat memantau secara real time SKPD mana yang telah menyelesaikan DPA dan SKPD mana yang belum, berikut dengan jumlah DPA dan besaran anggaran yang dibuat dalam DPA tersebut. Selesai tahapan perencanaan, Simral meliputi aspek penatausahaan keuangan. Pada wilayah ini diinput segala bentuk kegiatan transaksi keuangan baik dari sisi pendapatan maupun pengeluaran. Proses belanja daerah yang dilakukan setiap SKPD seperti pembuatan SPD, SPP, SPM, SP2D, Buku Besar dan sebagainya semua masuk dalam proses manajemen Simral. Demikian pula dalam hal proses pendapatan. Dengan diinputnya segala aktifitas keuangan dalam sistem yang online, maka progress pengeluaran dan pendapatan daerah akan dengan mudah diketahui dan tentunya akan menjadi acuan dalam mengontrol keuangan daerah serta memantau tingkat penyerapan anggaran SKPD. Simral juga meliputi Pelaporan yang wujudnya adalah pelaporan akuntansi berbasis akrual, yang merupakan pola pelaporan relatif baru dari pola pelaporan akuntansi sebelumnya yang berbasis kas. Setiap alur kerja yang ada pada Simral mengacu pada Peraturan Perundang-Undangan yang berlaku, seperti Peraturan Menteri Dalam Negeri (Permendagri) Nomor 13 Tahun 2006 Tentang Pedoman Pengelolaan Keuangan Daerah, Permendagri Nomor 55 Tahun 2008 Tentang Tata Cara Penatausahaan dan Penyusunan Laporan Pertanggung Jawaban Bendahara Serta Penyampaiannya, dan Permendagri Nomor 64 Tentang Penetapan Standar Akuntansi Berbasis Akrual pada Pemerintah Daerah. Sistem aplikasi E-Musrenbang yang berbasis internet ini, sehingga penerapannya tidak hanya sesuai dengan UU No. 25 tahun 2004 tentang sistem perencanaan pembangunan melainkan Inpres No. 3 ta- 
Tersedia Online di http://journal.unismuh.ac.id/index.php/otoritas

Otoritas : Jurnal Ilmu Pemerintahan, 7 (1), April 2017, 24

hun 2003 tentang Kebijakan Strategi Nasional E-Government.

Tentu hal ini menjadi daya tarik masyarakat dalam mewujudkan perencanaan pembangunan yang bersifatpartisipatif dan berkualitas. Perencanaan pembangunan secara transparan dan tersusun dengan baik. Sehingga masyarakat bisa melihat dan memonitor pelaksanaannya. Dalam Undang-undang Nomor 25 Tahun 2004, tentang Sistem Perencanaan Pembangunan Nasional telah dinyatakan bahwa perencanaan pembangunan bertujuan untuk mengoptimalkan partisipasi masyarakat. Partisipasi masyarakat dimaksudkan agar kebijakan yang dibuat oleh pemerintah menjadi lebih memiliki legitimasi. Partisipasi masyarakat untuk setiap kebijakan publik adalah proses mengekspresikan gagasan.

Perencanaan sebagai proses yang bersifat sistematis, terkoordinir dan berkesinambungan, sangat terkait dengan kegiatan pengalokasian sumberdaya, usaha pencapaian tujuan dan tindakantindakan di masa depan. UU No. 25 tahun 2004 menjelaskan bahwa pendekatan politik dalam perencanaan pembangunan terwujud dalam bentuk penjabaran agenda pembangunan yang ditawarkan presiden atau kepala daerah ke dalam rencana pembangunan jangka menengah. Pendekatan teknokratik merujuk pada perencanaan yang didasarkan pada metode dan kerangka berpikir ilmiah suatu lembaga atau satuan kerja sesuai dengan fungsinya. Perencanaan dengan pendekatan partisipatif dilaksanakan dengan melibatkan semua pihak yang berkepentingan terhadap pembangunan. Dua pendekatan terakhir, yakni pendekatan atas-bawah dan bawah-atas dilaksanakan menurut jenjang pemerintahan, yang dalam prosesnya terwujud dalam bentuk musrenbang di berbagai tingkat pemerintahan.

Sedangkan pembangunan yang bermuara pada pendekatan humanis adalah suatu proses pembangunan yang mem- berikan perhatian terhadap persoalan peningkatan martabat kemanusiaan. Implikasinya, pada persoalan etika, dan moralitas sebagai landasan dan tujuan pembangunan. Artinya, sebagai landasan pembangunan, dalam melaksanakannya ada etika yang harus diperhatikan. Sedangkan sebagai tujuan pembangunan, etika pembangunan tersebut harus menjadi arah dan sasaran pembangunan. Dengan demikian maka akan tercapainya perpaduan antara tatanan negara yang demokratis dengan sikap dan perilaku masyarakat yang manusiawi.

Menurut Magnis Suseno paradigma pembangunan humanis memiliki 3 prinsip etis yaitu, pembangunan harus menghormati hak-hak asasi manusia, adanya pembangunan yang demokratis, dan prioritasnya harus menciptakan taraf minimum keadilan sosial (Suseno, 1979). Adapun tujuan pembangunan dari Pendekatan Humanis antara lain, Human Capital, Growth With Equity, Social Capital \& Social Development, dan Human Development (Tjokroamidjojo, 2001).

Berbicara mengenai inovasi sistem perencanaan pembangunan berparadigma masyarakat, salah satu kota di Jawa Timur yang telah berhasil menggunakan sistem E-Musrenbang dalam proses perencanaan pembangunan sejak tahun 2010 adalah Kota Surabaya. Selama kurang lebih 5 tahun, Kota Surabaya telah berhasil menerapkan sistem berbasis teknologi, informasi dan komunikasi tersebut dan dinilai mampu memperluas akses masyarakat dalam memberikan usulan pada proses perencanaan pembangunan.

Dalam sistem E-Musrenbang yang dikelola oleh Badan Perencanaan Pembangunan Kota Surabaya, usulan masyarakat terhadap proses perencanaan pembangunan dapat dimulai dari tingkat RW. Setiap RW memiliki akses untuk login ke sistem tersebut dengan memberikan 2 usulan utama dan 1 usulan cadangan dalam proses perencanaan pembangunan.

Copyright (C) 2017, Otoritas : Jurnal Ilmu Pemerintahan, p-ISSN: 2088-3706, e-ISSN: 2502-9320 
Kemudian usulan dari RW tersebut diteruskan ke Kelurahan. Kemudian dari tingkat kelurahan, pihak kelurahan memiliki kewenangan untuk memetakan usulan dan merencanakan usulan dari RW sesuai dengan gambaran maupun peta yang kemudian mengajukannya ke pihak Kecamatan.

Setelah memperoleh pengajuan usulan dari pihak kelurahan, pihak Kecamatan pun memiliki kewenangan untuk menolak atau menyetujui usulan. Jika telah disetujui oleh kecamatan, maka usulan dapat dilanjutkan ke Satuan Kerja Perangkat Daerah yang kemudian akan melakukan survei terhadap usulan-usulan yang disetujui.

Berbicara mengenai hakekat otonomi daerah dan penyempurnaan sistem perencanaan pembangunan antara lain semakin dekatnya proses pengambilan kebijakan dengan masyarakat dan semakin besar peluang partisipasi masyarakat di dalam perencanaan pembangunan. Yang lebih penting lagi sebenarnya adalah sejauh mana masyarakat peduli dan mempunyai rasa memiliki atas kegiatan pembangunan di wilayahnya. Rasa memiliki akan terbangun ketika aspirasi yang mereka sampaikan terakomodir di dalam APBD. Mencermati secara singkat terhadap sistem E- Musrenbang Kota Surabaya sebagai salah satu sistem perencanaan pembangunan daerah, bahwa pentingnya keterlibatan masyarakat di dalam penyusunan perencanaan pembangunan sangat ditekankan dalam UU 25/2004. Pendekatan partisipatif yang dianut undang-undang ini setidaknya dapat dilihat dari empat pasal yang menyebutkan partisipasi masyarakat di dalamnya (Pasal 2, Pasal 5, Pasal 6 dan Pasal 7). Jika dianalisa dalam proses E- Musrenbang, ide dasarnya adalah membuka kesempatan yang luas kepada masyarakat untuk memberikan usulan terhadap proses pembangunan. Namun jika dilihat secara mendalam bahwa proses pembuatan kebijakan masih tergantung pada faktor ekonomi politik hubungan antar kelompok instansi- instansi pemerintah. Sehingga lebih jauh jika dikaitkan dengan upaya pengentasan kemiskinan dan pencapaian sasaran-sasaran dalam Millennium Development Goals (MDGs), tampaknya partisipasi yang telah berlangsung dalam proses E-Musrebang masih jauh dari harapan. Blair (2000) menyatakan bahwa setelah partisipasi berjalan, masih ada isu-isu selanjutnya yang perlu ditangani sebelum kemiskinan bisa teratasi, yaitu representasi, pemberdayaan, dan adanya distribusi manfaat untuk semua pihak. Brinkerhoff dan Crosby (2002) melihat partisipasi dari dua dimensi praktis, yakni sisi suplai dan permintaan. Jika partisipasi ingin berjalan efektif, mereka memandang perlunya sisi suplai yakni instansi penyelenggara untuk bersikap menerima masukan dari pihak luar, transparan, terbuka serta mempunyai kewenangan yang memadai. Dari sisi permintaan, terjaringnya aspirasi masyarakat tergantung antara lain pada lingkungan yang kondusif untuk berlangsungnya partisipasi, adanya tradisi partisipasi dan kemampuan masyarakat dalam berkelompok dan menyampaikan tuntutan mereka (Komarudin \& Siagian, 2007). Sedangkan dalam hal keterwakilan dan kemampuan menangkap aspirasi, keterwakilan dalam akses E- Musrenbang belum cukup menjamin aspirasi dari bawah tersampaikan atau menjadi bagian dari pengambilan keputusan di tahap selanjutnya. Perlu dilihat sejauh mana wakil masyarakat merepresentasikan kelompoknya dan mempunyai kekuatan serta kemampuan menyampaikan aspirasi dengan dukungan suasana yang kondusif. Dalam proses penjaringan aspirasi, peluang untuk menyampaikan aspirasi belum sepenuhnya diberikan secara luas kepada masyarakat. Aspirasi atau usulan hanya diberikan kepada beberapa pihak saja dalam hal ini elite di tingkat RW atau Kelurahan. Selain itu, perubahan sistem pemerintahan dan penyempurnaan 
Tersedia Online di http://journal.unismuh.ac.id/index.php/otoritas

Otoritas : Jurnal Ilmu Pemerintahan, 7 (1), April 2017, 26

mekanisme serta proses penjaringan usulan melalui sistem teknologi dan informasi seperti E- Musrenbang ini tampaknya belum mengurangi peluang terjadinya penyimpangan dalam perencanaan pembangunan. Elite capture sebagai suatu fenomena masih terjadi dalam setiap proses musrenbang. Dalam hal ini elite capture dipahami sebagai suatu sikap atau tindakan yang dilakukan orang atau sekelompok orang untuk mempengaruhi pembuatan kebijakan atau keputusan agar hasilnya memberikan keuntungan bagi mereka sendiri. Secara lebih luas, fenomena ini tidak hanya terkait pada sistem tetapi juga manfaat pembangunan, yang bentuknya dapat berupa materi ataupun non materi, seperti informasi dan bantuan pembangunan lainnnya (Komarudin \& Siagian, 2007). Bagian yang seharusnya sampai kepada masyarakat yang paling bawah dan yang paling berhak (umumnya yang miskin) tidak lagi utuh diterima. Sekalipun diakui cukup sulit untuk membuktikan secara jelas adanya penyimpangan dalam proses E-Musrenbang, Misalnya, sekalipun usulan bersumber dari RW dan kelurahan, tetapi yang memberikan validasi usulan kepada pemerintah kota adalah kecamatan. Ada indikasi bahwa banyak usulan dari tingkat RW dan kelurahan yang tidak divalidasi oleh pihak kecamatan meskipun usulan tersebut sangat dibutuhkan masyarakat.

Meski terlepas dari berbagai kekurangan yang ada, sistem E- Musrenbang setidaknya menjadi inovasi dalam sistem perencanaan pembangunan di negara ini dimana selama ini masyarakat menginginkan sebuah forum atau kontak sosial antara warga dengan pemerintah dalam perencanaan pembangunan daerah. Sistem yang berpijak pada transparansi dan partisipasi masyarakat yang luas telah mampu meringkas serta mempermudah proses penjaringan usulan masyarakat dalam proses perencanaan pembangunan selama ini.
Dalam hal transparansi, ada sisi positif dimana usulan- usulan yang disetujui oleh pemerintah pun dibuka kepada publik agar masyarakat dapat mengawal proses pembangunan di daerahnya. Sisi positif lain dari E- Musrenbang antara lain, mampu menjamin keakuratan data rencana program dan kegiatan pembangunan daerah, mampu memastikan ketepatan sasaran kegiatan, mampu mempermudah pengelompokan jenis usulan pekerjaan, lebih mudah memperkirakan kebutuhan anggaran yang dibutuhkan atas usulan kegiatan yang diajukan masyarakat dengan cepat dan tepat.

\section{Kesimpulan}

Perencanaan Pembangunan merupakan bagian terpenting dalam proses pembangunan di sebuah negara. Pasalnya, kualitas pembangunan akan dinilai dari proses perencanaan yang tepat. Di Indonesia, proses perencanaan pembangunan berubah mengikuti perkembangan rezim pemerintahan yang ada. Setelah orde baru tumbang, perubahan mendasar pada sistem pemerintahan desentralistik otomatis merubah pula sistem perencanaan pembangunan yang didasari UU No. 25 tahun 2004 tentang Sistem Perencanaan Pembangunan Nasional. Sistem perencanaan yang diatur dalam UU No. 25 tahun 2004 dan aturan pelaksanaannya menerapkan kombinasi pendekatan antara top-down dan bottomup, yang lebih menekankan cara-cara aspiratif dan partisipatif, sehingga hal tersebut diwujudkan melalui proses musyawarah perencanaan pembangunan atau Musrenbang di berbagai tingkatan mulai kelurahan hingga Nasional.

Seiring dengan era globalisasi dan perkembangan modernisasi, dengan dasar tetap menjamin ketebukaan dan partisipasi masyarakat dalam perencanaan pembangunan, maka lahir sebuah inovasi perencanaan pembangunan berbasis teknologi informasi 
Tersedia Online di http://journal.unismuh.ac.id/index.php/otoritas

Otoritas : Jurnal Ilmu Pemerintahan, 7 (1), April 2017, 27

yakni E- Musrenbang. E- Musrenbang lahir sebagai sebuah inovasi perencanaan pembangunan berbasis IT untuk membuka partisipasi masyarakat selebar- lebarnya terhadap berbagai usulan pembangunan. Di sisi lain, keberadaan EMusrenbang juga dinilai mampu memotong proses- proses panjang penjaringan usulan pembangunan di masyarakat agar usulan yang masuk lebih tepat, terarah dan akurat. Tentunya keberadaan EMusrenbang ini, penerapannya tidak hanya sesuai dengan UU No. 25 tahun 2004 tentang sistem perencanaan pembangunan melainkan Inpres No. 3 tahun 2003 tentang Kebijakan Strategi Nasional E-Government. Pun sistem E- Musrenbang ini mampu dijadikan sebuah pelajaran penting bagi perencanaan pembangunan berparadigma masyarakat, dimana masyarakat tidak hanya dijadikan objek melainkan subjek pembangunan.

\section{Ucapan Terima Kasih}

Alhamdhulillah, Puji Syukur dan Ucapan terima kasih teriring doa kami haturkan kepada pihak yang membantu proses penelitian penulis. Terima kasih secara khusus kami haturkan kepada Pimpinan dan Dosen Sejawat di Program Studi Ilmu Pemerintahan pada Universitas Darul Ulum, Jombang.

\section{Daftar Pustaka}

Angeline, M., Evelina, L., \& Siregar, V. M. (2016). Towards Cyber City: DKI Jakarta and Surabaya Provincial Government Digital Public Services. Humaniora, 7(4), 441-451.

Brinkerhoff, D. W., \& Crosby, B. (2002). Managing policy reform: Concepts and tools for decision-makers in developing and transitioning countries. Bloomfield, CT: Kumarian Press.

Dasgupta, P. (2004). World Poverty: Causes and Pathways. World Bank's Annual Bank
Conference on Development Economics (ABCDE) held in Bangalore, May 2003. The Proceedings of the World Bank Conference on Development Economics.

Kementerian PPN/ Bappenas. (2013). Ringkasan Sewindu Implementasi Undang Undang Nomor. 25 tahun 2004 dalam perspektif Stakeholders. Jakarta: Kementerian PPN/ Bappenas.

Komarudin, H., \& Siagian, Y. (2007). Sudahkah aspirasi masyarakat terakomodir dalam rencana pembangunan?: pelajaran dari sebuah aksi kolektif di Jambi (No. CIFOR Governance Brief no. 34 (b), p. 12p). Center for International Forestry Research (CIFOR), Bogor, Indonesia.

Masrizal, M. (2016). Tinjauan Sosiologis Perencanaan Pembangunan Berbasis Kamus E-Musrenbang. Jurnal Sosiologi Pendidikan Humanis, 1(1), 29-39.

Mustopadidjaja, A. R. (2012). Bappenas Dalam Sejarah Perencanaan Pembangunan Indonesia 1945-2025. Jakarta: LP3ES.

Suseno, F. M. (1979). Etika Dasar; Masalah-Masalah Pokok Filsafat Moral. Jakarta: Kanisius

Teguh, A. (2004). Kemitraan dan ModelModel Pemberdayaan. Yogyakarta: Gava Media.

Tjokroamidjojo, B. (2001). Good governance: paradigma baru manajemen pembangunan. Jakarta: Lembaga Administrasi Negara 